\title{
The Ecology and Economics of Florida's Ranches ${ }^{1}$
}

\author{
Martin B. Main, M.E. Swisher, Jeff Mullahey, William DeBusk, Avrum J. Shriar, George W. Tanner, \\ James Selph, Patrick Hogue, Patrick Bohlen and Ginger M. Allen ${ }^{2}$
}

\section{Ranching in Florida}

Ranching is important to Florida's economy and environment. Of Florida's 34.5-plus million acres of land, 10.2 million acres were utilized for farmland in 2003 , with the majority partially or totally used for cattle production. Cattle production contributed more than $\$ 348$ million to the state's economy in 2003 . Ranching helps protect water resources, provides natural greenways for wildlife and recreation, and preserves many components of the natural landscape. Both the environmental and economical health of ranching are therefore critical to the state's citizens.

The economic importance of ranching in Florida extends beyond the income it generates. The tax rates on agricultural lands in Florida are lower than the rates on industrial and residential properties.

However, agricultural lands "take back" - in the form of services - only part of the tax dollars that

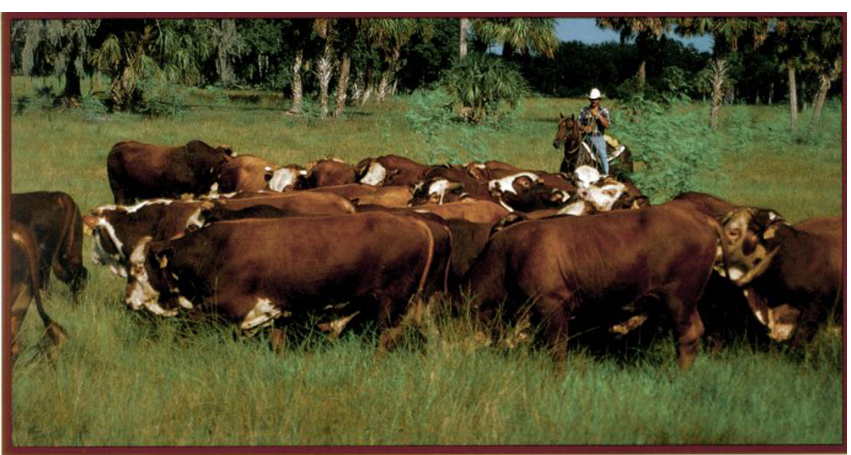

Figure 1. Ranching contributes hundreds of millions of dollars to Florida's economy. Photo: UF/IFAS

they pay into the state and county coffers. In counties that have done in-depth studies comparing the public funds spent on services to the tax dollars collected, agricultural properties typically use 40 cents or less of every tax dollar collected for services. Residential and industrial lands often require $\$ 1.25$ or more of services for every tax dollar collected.

1. This document is WEC 187, one of a series of the Wildlife Ecology and Conservation Department, Florida Cooperative Extension Service, Institute of Food and Agricultural Sciences, University of Florida. First published as Extension document SS-SA-8, February 2000; revised September 2004. Please visit the EDIS Web site at http://edis.ifas.ufl.edu.

2. Martin B. Main, Associate Professor and Wildlife Extension Specialist; University of Florida/IFAS Southwest Florida Research and Education Center, Immokalee, FL; M.E. Swisher, Professor and Associate Director of International Programs, Cooperative Extension Service, University of Florida/IFAS, Gainesville FL; Jeff Mullahey, Professor, University of Florida/IFAS West Florida Research and Education Center, Milton, FL; William DeBusk, Assistant Research Scientist, University of Florida/IFAS West Florida Research and Education Center, Milton, FL; Avrum Joseph Shriar, Department of Urban Studies and Planning, Virginia Commonwealth University, Richmond, VA; George W. Tanner, Professor, Department of Wildlife Ecology and Conservation, Cooperative Extension Service, University of Florida/IFAS, Gainesville, FL; Jim Selph, County Extension Director and Livestock Extension Agent, Desoto County, FL; Patrick J. Hogue, Livestock Extension Agent, Okeechobee County, FL; Patrick Bohlen, Assistant Research Biologist, MacArthur Agro-ecology Research Center, Lake Placid, FL; and Ginger M. Allen, senior biologist, Department of Wildlife Ecology and Conservation, University of Florida/IFAS Southwest Florida Research and Education Center, Immokalee, FL. 
As a state, Florida ranks twelfth in the U.S. in the number of beef cows with 1.74 million head of cattle. Florida ranches are cow-calf operations. They produce calves that are sold at weaning and shipped to other states in the southeast, midwest, and west, where they are fattened and eventually harvested. The states that have a larger number of beef cattle than Florida generally have multiple kinds of cattle operations, such as cow-calf, backgrounding, and feeder operations.

Florida has a rich history of cattle ranching and is one of the leading states in cattle production. Nonetheless, both the number of ranches and the amount of land in cattle ranches decrease every year. Ranching produces a net gain only in some years. The cattle market is cyclical. With time, producers suffer net losses as well as enjoy net gains. Any unexpected or additional expenses that must go into annual production costs can cause a producer to lose money for an extended period of time. The precarious economic balance of ranching leads to a declining number of ranches and land in ranching. As so often happens in Florida, land that goes out of ranching is apt to be developed. Given the economic and environmental benefits of ranching to Florida's citizenry as a whole, any effort that helps sustain the industry is also important to the citizens of the state.

\section{Florida Ranches Help Preserve Wildlife}

Conserving wildlife is important to Florida both from an ecological and utilitarian standpoint. Wildlife enrich our lives and are indicators of the health of the land on which we live. From a utilitarian standpoint, nature-based tourism, which relies heavily on wildlife viewing, is one of the most rapidly growing industries worldwide and is of increasing importance in Florida. In 1996, 1.8 million people spent $\$ 1.7$ billion on watchable wildlife activities in Florida.

Cattle ranches contain much of Florida's remaining native habitat, particularly in south Florida. Consequently, cattle ranches have an important role in the future of Florida's wildlife. For example, freshwater wetlands have declined by more than 50\% in Florida since European settlement. Yet, they still exist as integral components of many ranches, contributing to the productivity of both wildlife and livestock.

The mix of native habitats found within and among ranches, such as marshes, swamps, woodlands, and others, is key to providing food and cover that support a diversity of species, each with its own particular needs. Even improved pasture provides benefits to some species of wildlife, particularly when wetlands and other native habitats are present.

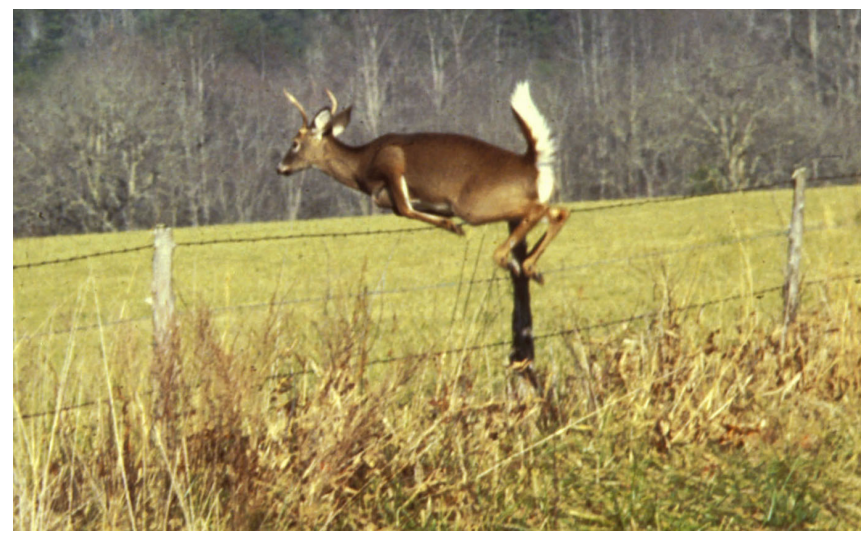

Figure 2. White-tailed deer and other wildlife utilize mixed habitats on Florida ranches. Photo: U.S.F.W.S.

More than 400 species of birds have been documented in Florida, many of which utilize habitats found on ranchland during part or all of the year. Many birds are seasonal visitors to Florida. Some, such as Sandhill cranes and Swallow-tailed kites, seek Florida as a seasonal destination. Others, including many songbirds and shorebirds, depend on habitats found on ranchland to provide important resting and feeding stops during flights to and from South and Central America. Consequently, native habitat in Florida has global implications for the survival of many species of migratory birds.

Many of Florida's rarest species, such as the Caracara and the endangered Florida panther, depend upon ranchland for their continued survival. For example, the Florida Fish and Wildlife Conservation Commission estimates that more than $50 \%$ of habitat used by Florida panthers exists on privately owned land, most of which supports cattle ranching.

The loss, degradation, and fragmentation of wildlife habitat are the principal reasons for declines 


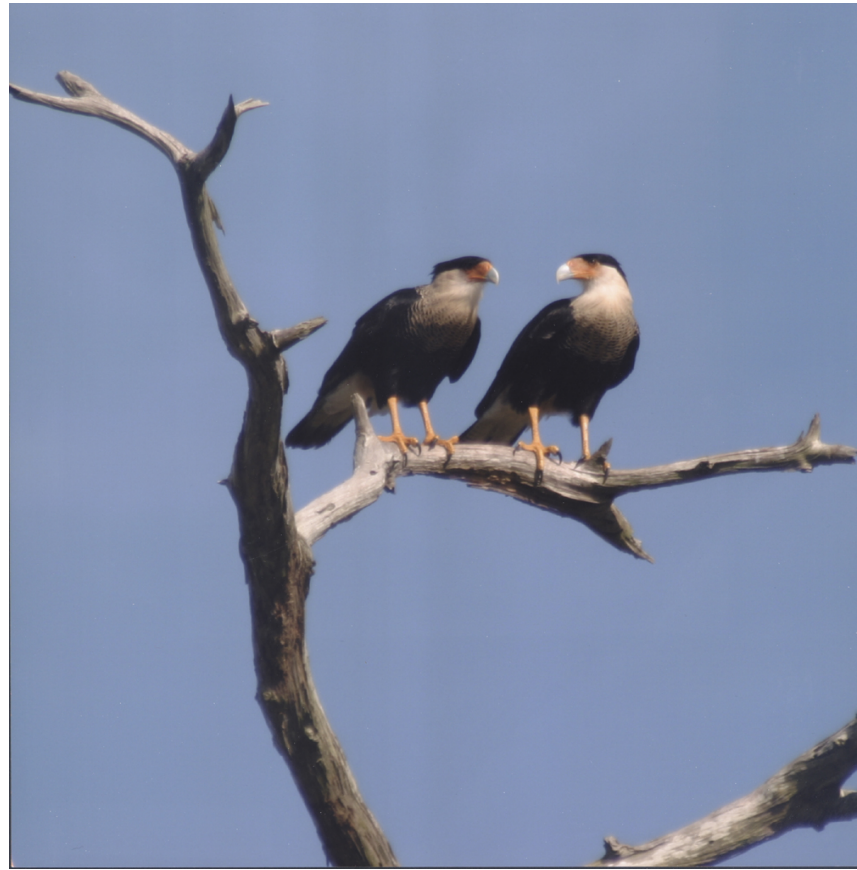

Figure 3. Audubon's Crested Caracaras (Caracara plancus audubonii) are found on Florida ranches. Photo: Maryle Barbe

in wildlife populations and biodiversity worldwide. Of particular concern is Florida's rapidly growing human population, which contributes to urban sprawl, the accompanying loss of wildlife habitat, and the conversion of native habitats to higher-intensity land uses.

Good land stewardship of remaining habitats is critical to maintaining healthy wildlife populations. Land management practices, such as prescribed fire, exotic weed control, and grazing, are routinely used by cattle ranchers to reduce shrubby understory, stimulate plant growth, and maintain habitat productivity that benefits both livestock and wildlife. On a statewide scale, the maintenance of native habitats on cattle ranches and other agricultural lands make possible the movement of wildlife and the interchange of genetic material between different areas and breeding populations, which is vital to the long-term survival of wildlife populations in Florida.

\section{Florida's Grazing Lands}

The number of cattle that a ranch can support varies from as few as 18 to as many as 320 animals per square mile. The kind of forage available to the cattle is one important factor in determining the stocking rate--the number of cows that can live on an acre. The three main kinds of grazing lands in Florida are: improved pasture, which has been planted with an introduced higher forage value grass; unimproved pasture, which contains an introduced grass (such as bahia) but is not managed for high production; and native range, which are open native plant communities. Improved pastures support more animals per unit area than unimproved pasture or range, but also require more management. Bahia grass pastures, for example, typically produce about 5,000 pounds of forage per acre each year. Native range, on the other hand, produces only half as much forage, 2,000-2,500 pounds per acre per year.

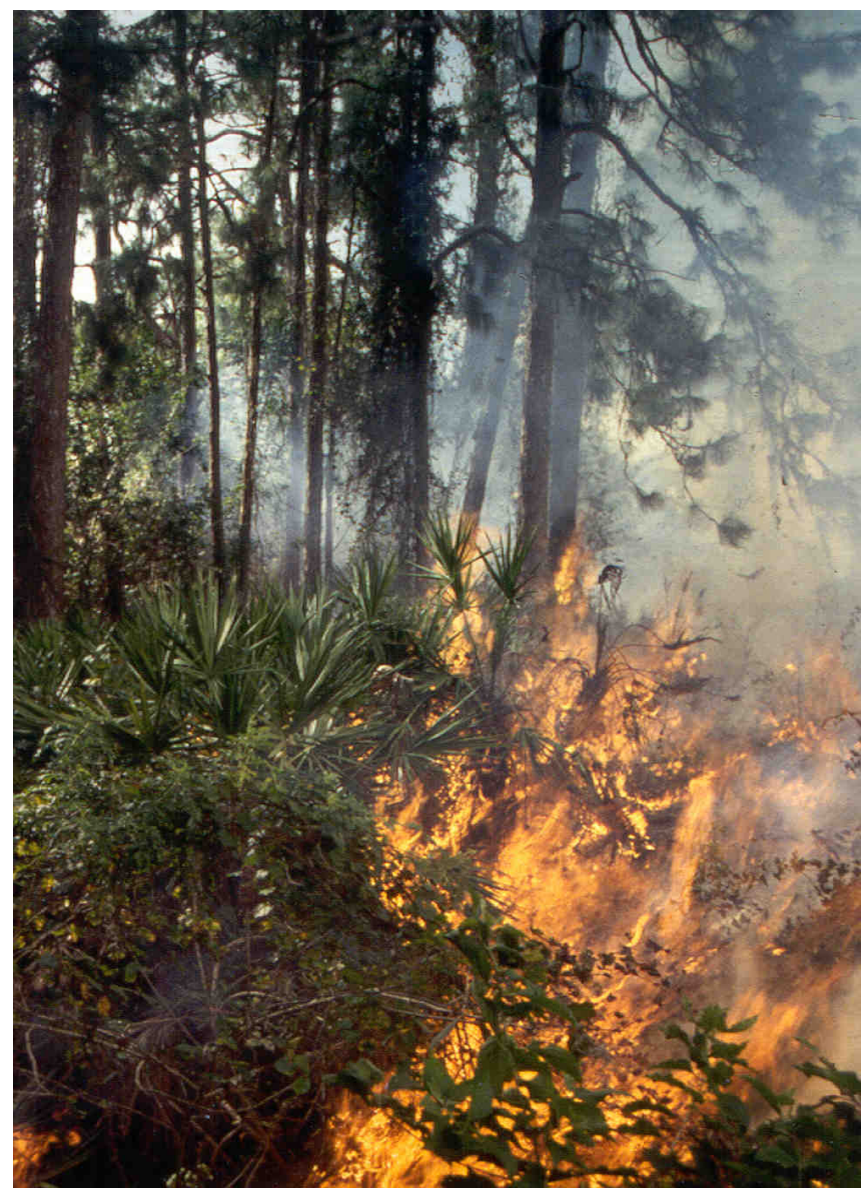

Figure 4. Controlled burn. Photo: Martin Main

All grazing land, including native range, requires management. Ranchers use prescribed burning, roller chopping, and controlled grazing to manage both range and pasture. Range and pasture are burned to increase forage quality, improve the production of desirable plants, and lower fuel loads to reduce the risk of uncontrolled wildfires. Burning is one way to increase the presence of what range scientists call decreaser plants - plants that are nutritious and 
palatable to cattle and decrease in abundance when overgrazed. Overgrazing, on the other hand, can increase the presence of increaser plants that are not palatable to cattle. Ranchers divide their grazing land into several individual pastures, judging how many animals can graze each pasture and for how long to get the maximum benefit from their forages.

The main pests on pastures are weeds and insects. Weeds lower forage production and quality. A healthy pasture that has not been overgrazed is the best defense against weeds, but ranchers occasionally rely on herbicides, hand weeding, burning, and mowing to control weeds. Ranchers apply herbicides selectively to problem weed areas. A 1996 survey of Florida ranchers showed that $35 \%$ of north Florida and $57 \%$ of south Florida participants did apply herbicide that year, but they treated only $1 \%$ and $7 \%$ of their respective ranchlands. The two main insect problems are mole crickets and armyworms. Control measures include toxic baits, biological control agents, and insecticides.

There are important differences between cattle ranches in the northern and southern parts of the state. Ranches are generally small in north Florida, with smaller herds. They rely almost entirely on improved pasture. South Florida's ranches are generally larger and are much more apt to incorporate unimproved pasture or native range in their forage program.

\section{Ranching and Florida's Water}

Excess nutrients from farmlands contribute to non-point source pollution. Unlike point source pollution from industry or sewage treatment plants, non-point source pollution comes from a wide variety of diffuse sources. Nutrient runoff is a major concern in Florida due to the large area of surface water in our state that is sensitive to nutrient inputs, especially lakes and freshwater wetlands.

Florida soils, for the most part, require applying plant nutrients to achieve economically acceptable levels of forage production. The kind and amount of fertilizer applied depend on soil characteristics and the type of forage present. Soil type and condition, in conjunction with the condition of vegetation in pastures and native range, influence how and where

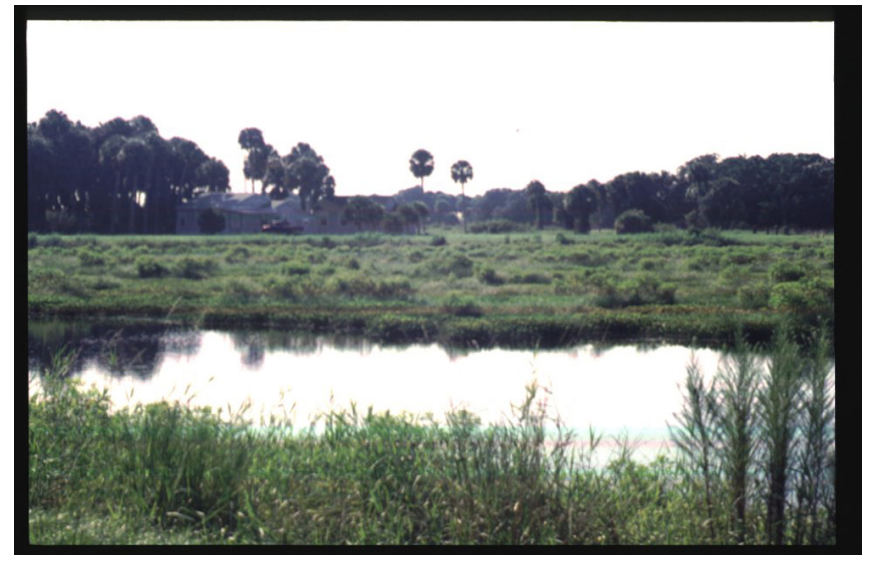

Figure 5. Wetlands on Florida ranches are important filtering systems and ground water recharge areas. Photo: Martin Main

water moves after it reaches the soil through precipitation or irrigation. Most Florida soils are sandy, especially in the central portion of the state where the majority of beef cattle are produced. These soils generally have a very low capacity for retaining nutrients. Therefore, nitrogen and phosphorus in fertilizer or animal manure can readily wash through these sandy soils into the shallow ground-water and can ultimately impact nearby lakes, streams, and other water bodies. The rancher must therefore balance the economic gains derived from fertilizer application with the need to protect water resources.

Ranchers regularly fertilize improved pastures, but usually not unimproved pastures and never native range. The amount of fertilizer applied per acre is small compared to most crops or urban landscapes. Unlike most other farming systems or urban landscapes, cattle recycle much of the nutrients through their manure and urine. Beef cattle ranches, therefore, are not a major source of nutrients to surface water when compared to more intensive agricultural or urban uses, especially the large tracts of unfertilized native range. Improved pastures that have received long-term fertilizer inputs are stocked at higher rates and are more likely than native range to be a source of excess nutrients. Even here, however, fertilizer use is low and not apt to be a problem in well managed pastures.

Wetlands are vital to the health of our environment and are an important part of the landscape on many Florida cattle ranches. These wetlands provide critical habitat for numerous 
wildlife. Many of our endangered and threatened species, such as the wood stork, are dependent upon wetlands for their survival and use wetland habitats on Florida ranches. Wetlands perform the same function for our ecosystem as kidneys do for our bodies: They filter and remove pollutants. However, the nutrient filtering capacity of wetlands can be exceeded if they receive too many nutrients.

Ranchers, therefore, need to think carefully about how their management practices affect the wetlands on their ranches. Ranches and the wetlands on them play an important role in retaining excess water and recharging ground water supplies. In urban areas, much of the rain runs off the surface, is collected into drains, and discharges into the ocean. Rainfall reaching ranchlands and their wetlands infiltrates into the ground. These landscapes can retain water and help prevent flooding after storm events. They also provide critical recharge of the groundwater, the major source of potable water in Florida. Retention and restoration of wetlands on Florida's cattle ranches can benefit all citizens by protecting water quality and maintaining our supply of water.

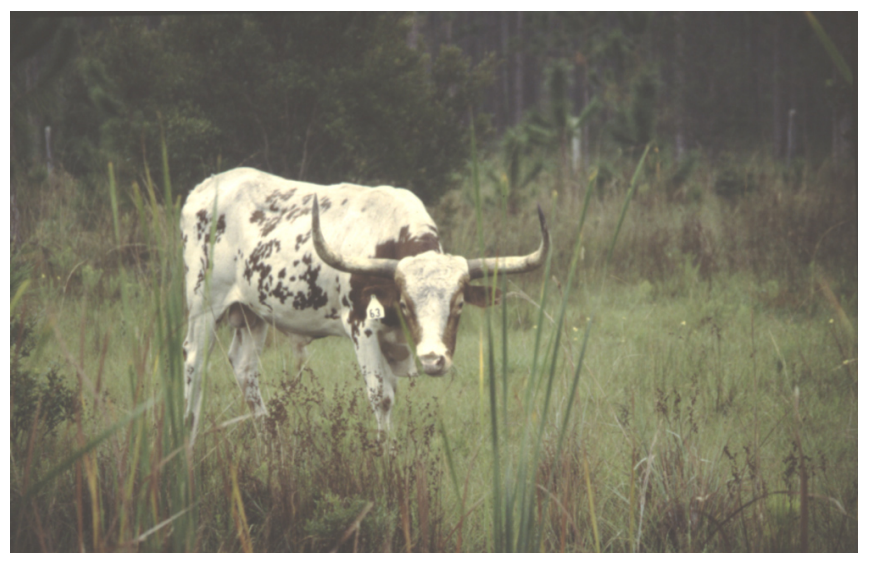

Figure 6. Well-managed ranches provide both environmental and economic benefits. Photo: UF/IFAS

\section{Florida's Ranches: Complex Ecosystems Providing Public Services}

Florida's ranches are among the most complex of the managed ecosystems. Ranchers must manage every component in the system with an eye to both profitability and the environment. Well managed ranches provide multiple benefits to Florida's citizens. They support our economy through their contributions in taxes and economic stimulation.
They protect our environment through preserving habitat for wildlife, protecting our water supplies, and conserving green space.

\section{References and Additional Information}

Carter, D. R. and E. J. Jokela. 2002. Florida's Renewable Forest Resources, CIR1433, University of Florida/IFAS, Gainesville, FL., available at http://edis.ifas.ufl.edu/FR143.

Florida Agriculture Statistical Service, available at http://www.nass.usda.gov/fl/.

Florida Fish and Wildlife Conservation Commission. 1997. Checklist of Floridas Birds. Tallahassee, FL.

Florida Panther Net, Florida Fish and Wildlife Conservation Commission, available at http://panther.state.fl.us.

Hogue, P., Jennings, E., Kunkle B., Pate, F., Richey, E., Ward, R., and R. West. 1999. Florida First--Beef Cattle. Florida First Base Papers, University of Florida/IFAS, Gainesville, FL. Pp.181-192.

Kalmbacher, R. S. 2002. Managing South Florida Range for Cattle, document SS-AGR-105, University of Florida/IFAS, Gainesville, FL., available at http://edis.ifas.ufl.edu/AG173.

Mullahey, J.J., Tanner, G. W., and Steve Coates 2002. Range Sites of Florida, CIR951, University of Florida/IFAS, Gainesville, FL., available at http://edis.ifas.ufl.edu/UW126.

Noss, R.F., and R.L. Peters. 1995. Endangered Ecosystems: A Status Report on America's Vanishing Habitat and Wildlife. Defenders of Wildlife, Washington, D.C. 132 pp.

Stevenson, H.M. and B. H. Anderson. 1994. The Birdlife of Florida. University Press of Florida, Gainesville, FL. 892 pp.

Swisher, M.E., Kunkle, W.E., Chambliss, C.G., and D.K. Clare. Cattle Production Can Help Protect and Preserve Florida Natural Resources. University 
of Florida/IFAS Cooperative Extension Service, Gainesville, FL. 4 pp. 